cell administration to young patients with systemic right ventricle pathology or pronounced abnormalities in structure, cellular composition, and functional responses to hemodynamic perturbations. ${ }^{5,8}$

To avoid the mistakes of premature cell therapy trials in adult patients, proponents of pediatric cell therapy should ideally perform rigorous optimization of cell therapy in preclinical models of congenital heart disease. The resulting base of knowledge will provide the best opportunity for success in future clinical trials, preferably with adequately sized study populations and appropriate randomized, blinded trial design.

\section{References}

1. Gyöngyösi M, Haller PM, Blake DJ, Martin Rendon E. Meta-analysis of cell therapy studies in heart failure and acute myocardial infarction. Circ Res. 2018;123:301-8.
2. Epstein JA. A time to press reset and regenerate cardiac stem cell biology. JAMA Cardiol. 2019;4:95.

3. Sano S, Sano T, Ishigami S, Ito T. Cardiac stem cell therapy: Does a newborn infant's heart have infinite potential for stem cell therapy? J Thorac Cardiovasc Surg. 2022;163:242-7.

4. Garcia AM, Beatty JT, Nakano SJ. Heart failure in single right ventricle congenital heart disease: physiological and molecular considerations. Am J Physiol Hear Circ Physiol. 2020;318:H947-65.

5. Bittle GJ, Morales D, Deatrick KB, Parchment N, Saha P, Mishra R, et al. Stem cell therapy for hypoplastic left heart syndrome: mechanism, clinical application, and future directions. Circ Res. 2018;123:288-300.

6. Orlic D, Kajstura J, Chimenti S, Jakoniuk I, Anderson SM, Li B, et al. Bone marrow cells regenerate infarcted myocardium. Nature. 2001;410:701-5.

7. Assmus B, Schächinger V, Teupe C, Britten M, Lehmann R, Döbert N, et al. Transplantation of progenitor cells and regeneration enhancement in acute myocardial infarction (TOPCARE-AMI). Circulation. 2002;106:3009-17.

8. Lahm T, Douglas IS, Archer SL, Bogaard HJ, Chesler NC, Haddad F, et al. Assessment of right ventricular function in the research setting: knowledge gaps and pathways forward an official American Thoracic Society research statement. Am J Respir Crit Care Med. 2018;198:e15-43.

\title{
Commentary: Defining the role of stem cell therapy in neonatal cardiac regeneration
}

\section{Harold M. Burkhart, MD, ${ }^{\mathrm{a}}$ and M. Yasir Qureshi, MBBS ${ }^{b}$}

Over the past several years, preclinical and clinical studies about the potential cardiac application of stem cell therapy have been conducted extensively, primarily in adult ischemic heart disease. ${ }^{1,2}$ More recently, this potential therapeutic option has gained attention in the world of congenital heart disease. This has been due, in part, to the discovery that neonatal myocardium retains greater regenerative potential than adult heart tissue. ${ }^{3,4}$ Moreover, despite excellent surgical results in complex single-ventricle patients, we

\footnotetext{
From the ${ }^{\mathrm{a}}$ Division of Cardiovascular and Thoracic Surgery, University of Oklahoma Health Sciences Center, Oklahoma City, Okla; and ${ }^{\mathrm{b}}$ Pediatric Cardiology, Mayo Clinic, Rochester, Minn.

Disclosures: The authors reported no conflicts of interest.

The Journal policy requires editors and reviewers to disclose conflicts of interest and to decline handling or reviewing manuscripts for which they may have a conflict of interest. The editors and reviewers of this article have no conflicts of interest.

Received for publication Sept 2, 2020; revisions received Sept 2, 2020; accepted for publication Sept 3, 2020; available ahead of print Sept 10, 2020.

Address for reprints: Harold M. Burkhart, MD, Division of Cardiovascular and Thoracic Surgery, University of Oklahoma Health Sciences Center, PO Box 26901, WP-2230, Oklahoma City, OK 73105 (E-mail: Harold-burkhart@ouhsc. edu).

J Thorac Cardiovasc Surg 2022;163:249-50

$0022-5223 / \$ 36.00$

Copyright (C) 2020 by The American Association for Thoracic Surgery

https://doi.org/10.1016/j.jtcvs.2020.09.013
}

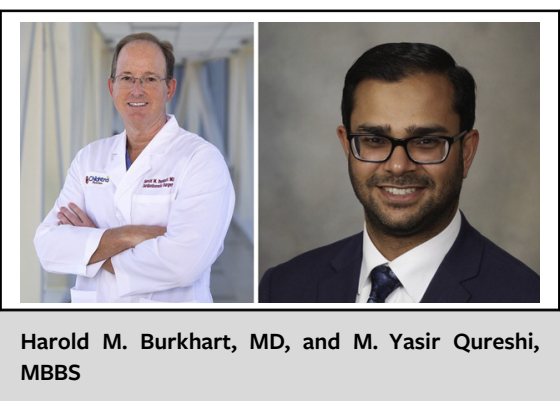

CENTRAL MESSAGE

Neonates have a higher cardiac regenerative potential when compared with adults, but much is yet to be learned regarding stem cell therapy in congenital heart disease.

have come to realize that it will take additional therapies to improve the long-term cardiac outlook for these children. Several cell types from many sources utilizing various delivery techniques are currently being investigated in multiple cardiac pathologies across the spectrum of patient age groups. Patients with single-ventricle physiology are deemed more suitable to study this potential treatment due to limited conventional options for treatment of their heart failure. It is important for cardiac care providers to 
understand these developing therapeutic strategies and possible mechanisms of cardiac regeneration.

Sano and colleagues ${ }^{5}$ provide an inclusive expert opinion on cardiac stem cell therapy with special attention given to the differences between neonatal and adult hearts. Emphasis is given to c-kit + cardiac progenitor cells and cardiosphere-derived cells (CDCs), but much of the discussion can be generalized to all cardiac stem cells. Key points to keep in mind from this review are:

1. Age of the patient matters: Neonatal heart tissue has demonstrated more regenerative potential and tends to regenerate with limited scarring.

2. Age of the cells matter: The CDCs derived from neonatal hearts were more abundant, demonstrated more c-kit expression, and showed more proliferative and differentiation potential when compared with children aged $>2$ years.

3. Because of the above, the hope is that neonatal congenital heart disease patients are more likely to show measurable benefits from cell-based therapy.

4. The mechanism of action of stem cell therapy is not clearly understood, but the following pathways have been proposed:

a. Paracrine effect: By secreting growth factors and subcellular particles (exosomes) that promote repair, regeneration, and remodeling.

b. Immune modulation: By timely suppression or activation of the immune system to promote the healing process. This may influence the decision about the timing of cell therapy to get maximal benefit.

c. Angiogenesis: By activating endogenous endothelial progenitor cells or by secreting growth factors that promote neovascularization.

d. Cardiogenesis: By differentiation into new cardiomyocytes. However, this pathway has largely been debunked. Paracrine induction of endogenous cardiac progenitor cells may still be a possibility.
5. Clinical trials: To date, 2 phase 1 clinical trials of stem cell therapy in congenital heart disease have been completed, both of which did not show any major concern about the safety or feasibility of this therapy. ${ }^{6,7}$ One phase 2 clinical trial has shown improvement in ejection fraction in CDC-treated patients $(+6.4 \%$ vs $+1.3 \%$ ) with single-ventricle physiology. ${ }^{8}$ Several other clinical trials are currently being conducted, most of which are focused on hypoplastic left heart syndrome and other single-ventricle lesions.

The authors present an excellent comprehensive review of the state of stem cell therapy in congenital heart disease. The increased regenerative potential of neonatal heart tissue is an encouraging discovery and promising for the development of novel therapeutic options. As we seek to define the role of stem cell therapy in congenital heart disease, much is still to be discovered about the best choices of patients, cell types, and methods (eg, route, dose, and timing) of administration of cell-based therapy.

\section{References}

1. Noiseux N, Mansour S, Weisel R, Stevens LM, Der Sarkissian S, Tsang K, et al The IMPACT-CABG trial: a multicenter, randomized clinical trial of CD133(+) stem cell therapy during coronary artery bypass grafting for ischemic cardiomyopathy. J Thorac Cardiovasc Surg. 2016;152:1582-8.

2. Rosengart TK, Patel V, Sellke FW. Cardiac stem cell trials and the new world of cellular reprogramming: time to move on. J Thorac Cardiovasc Surg. 2018;155: 1642-6.

3. Uygur A, Lee RT. Mechanisms of cardiac regeneration. Dev Cell. 2016;36:362-74.

4. Porrello ER, Olson EN. A neonatal blueprint for cardiac regeneration. Stem Cell Res. 2014;13(3 pt B):556-70.

5. Sano S, Sano T, Ishigami S, Ito T. Cardiac stem cell therapy: Does a newborn infant's heart have infinite potential for stem cell therapy? J Thorac Cardiovasc Surg. 2022;163:242-7.

6. Burkhart HM, Qureshi MY, Rossano JW, Cantero Peral S, O'Leary PW, Hathcock M, et al. Autologous stem cell therapy for hypoplastic left heart syndrome: safety and feasibility of intraoperative intramyocardial injections. J Thorac Cardiovasc Surg. 2019;158:1614-23.

7. Ishigami S, Ohtsuki S, Tarui S, Ousaka D, Eitoku T, Kondo M, et al. Intracoronary autologous cardiac progenitor cell transfer in patients with hypoplastic left heart syndrome: the TICAP prospective phase 1 controlled trial. Circ Res. 2015;116:653-64.

8. Ishigami S, Ohtsuki S, Eitoku T, Ousaka D, Kondo M, Kurita Y, et al. Intracoronary cardiac progenitor cells in single ventricle physiology: the PERSEUS (cardiac progenitor cell infusion to treat univentricular heart disease) randomized phase 2 trial. Circ Res. 2017;120:1162-73. 